\title{
Correction to: Examining socio-mathematical norms related to problem posing: a case of a gifted and talented mathematics classroom
}

\author{
Aslı Çakır ${ }^{1}$ (D) Hatice Akkoç ${ }^{2}$ (D) \\ Published online: 30 October 2020 \\ (C) Springer Nature B.V. 2020
}

Correction to: Educational Studies in Mathematics (2020) 105:19-34

https://doi.org/10.1007/s10649-020-09965-0

This article is intended for inclusion in the Special Issue on Affect in Mathematical Problem Posing: Conceptualization, Advances, and Future Directions of Research. It was however published in a separate issue, Volume 105 Issue 1 and is available at https://doi.org/10.1007 /s10649-020-09965-0.

Publisher's note Springer Nature remains neutral with regard to jurisdictional claims in published maps and institutional affiliations.

The online version of the original article can be found at https://doi.org/10.1007/s10649-020-09965-0

Hatice Akkoç

hakkoc@marmara.edu.tr

Aslı Çakır

aslicakir01@gmail.com

1 Institute of Educational Sciences, Marmara University, Istanbul, Turkey

2 Department of Mathematics and Science Education, Ataturk Faculty of Education, Marmara University, Istanbul, Turkey 